\title{
Policy Change Implication Toward Integrated Wonorejo Zone As a Strategic Economic Development Zone
}

\author{
Akbar Pandu Dwinugraha ${ }^{1^{*}}$, Mardiono ${ }^{2}$, Sarwono $^{2}$ \\ ${ }^{1 *}$ Master Program of Public Administration, Faculty of Administrative Science, University of Brawijaya, Malang \\ ${ }^{2}$ Faculty of Administrative Science, University of Brawijaya, Malang
}

\begin{abstract}
Integrated Wonorejo Zone is one of the development zone in Lumajang Regency with significant goals to improve potensial condition in three aspect namely tourism, agriculture and SMEs. Based on RTRW in 2008-2028, which was established in 2008, the development strategy of this zone is change. Integrated Wonorejo Zone was mentioned as a Strategic Economic Development Zone. This research describe and analyse about how the implication of policy change toward Integrated Wonorejo Zone. This research using method of descriptive research with qualitative approach as well as analysis of data by John Seidel about QDA (qualitative data analysis). The result of this research explain that the policy change implication, from description, implementation and implication point of view did not give significant expectation.
\end{abstract}

Key Words: Policy Change, Integrated Wonorejo Zone, Strategic Economic Development Zone.

\section{INTRODUCTION}

In the beginning, Integrated Wonorejo Zone in Lumajang Regency has goals as realization of Tri Program plus. It consists of agriculture, tourism, and small and medium enterprises. Tri Program Plus itself become one of the Lumajang Regency Action Program at the time and gain full support from local council to create and realize people dreams. Lumajang Regency introduced Wonorejo as a banana city (Kota Pisang) and change become pouch city (Kota Kantong). But in recent days, concept of Integrated Wonorejo Zone development is change. Those change included in RTRW (Spatial Planning) of Lumajang Regency in 20082028. Local government of Lumajang Regency arrange Integrated Wonorejo Zone as Strategic Economic Development Zone. Plan of strategic area in Integrated Wonorejo Zone directed to economic, social, culture and strategic development zone for environmental support. Change condition of Integrated Wonorejo Zone described from differentiation of facilities in each development period. First period is explain the first plan of Integrated Wonorejo Zone Development and second period is a condition of Integrated Wonorejo Zone after RTRW 20082028 Lumajang Regency executed.

Integrated Wonorejo Zone in first period established agriculture agency office besides

Corresponding Address:

Akbar Pandu Dwinugraha

Email : ap.dwinugroho@gmail.com

Address : Jl. Baluran 21 Malang, 65112 agriculture training and education, to improve professionalism in the field of agriculture. First period also develop Green House as a research site, to produce a variety of ornamental plants and other rare plants. Agro stand was also developed as a place of exhibition and sale of primary agriculture commodities from Lumajang Regency. Rest area built as a resting zone for visitors and at the same time for the convenience of travelers. Warehouse rabate become a market that sale all product, especially local product of Lumajang Regency. At the time, restaurant provide very satisfying food menu for customers. Central of Social Information Office provides information about Lumajang on education, health, agriculture, industry and business opportunities. Play Ground Area is a childrens game zone that combine technology and traditional concept, besides safe and comfortable. Consist of waterpark, bumper car and mono rail trains. The last for first period is Place of Worship, as prayer room for moslem visitors.

Facilities in second period of Integrated Wonorejo Zone different than former condition. Consist of water park, as a spatial form of pool and kids games. This place has been develop since the Integrated Wonorejo Zone were established. Circuit of motor cross, as a land that used for racing motor cross. Historically, this place was an agriculture training office. Outbond Arena is a place that utilize all building facilities around Integrated Wonorejo Zone. Central of handicraft become stores that sell original products of Lumajang. The last is Bird 
Competition Arena for bird competition event that held by Tourism Art and Culture office. The venues and zones utilize several part of Integrated Wonorejo Zone.

Policy change of development include in the process of development. But in fact, due to policy changes often afflict on the interests of important group in society or the self-interests of the public officials who must adopt them, many development analysis have been pessimistic about the possibilities for policy reform (Grindle, 1991). The goal is to analyze the policy change implication toward Integrated Wonorejo Zone as a strategic economic development zone.

Objectives of this research is to describe and analyze policy change implication toward Integrated Wonorejo Zone, describe and analyze consideration in changing the policy. We also describe and analyze the inovation which made to develop Integrated Wonorejo Zone as a strategic economic development zone in Lumajang Regency.

\section{MATERIAL AND METHODS}

Field data was generated through structured interview. Informant of this study encompasses persons who are related to the political changes, namely staffs of Promotion, staff of Tourism Attraction and Destination, Head of Statistic Division Department of Agriculture, and staff at Infrastructure Development BAPPEDA (Regional Development Agency).

\section{Documentation}

The data consisted of guide book of Integrated Wonorejo Zone Development, basic data of Tourism, Art and Culture office, RTRW 2008-2028 of Lumajang Regency, Regent Decision about team management of Integrated Wonorejo Zone.

\section{Observation}

We observed the condition on research site, and all place in Integrated Wonorejo Zone. All facilities, institution become supporting data for analysis.

\section{Data Analysis}

This research use Qualitative Data Analysis (QDA) from John V. Seidel (Fig. 1).

\section{Notice Things}

The notice things phase has been done to notice, write field data, interview the informant, gather the data and collect the data from Department of Agriculture (coordinator) and Bappeda as advisor of zone management. We make a note about historical description and performance of Integrated Wonorejo Zone in first period and gathering data about history, performance and description of Integrated Wonorejo Zone in second period. We classified the basic data and correlated it to the focus of research.

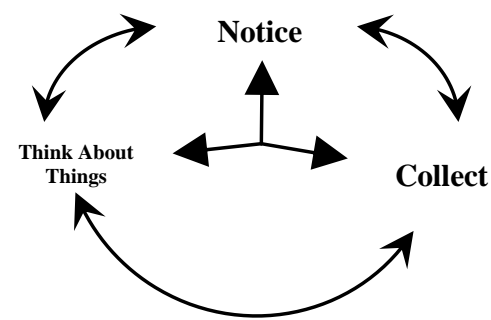

Figure 1. Model of Qualitative Data Analysis (Seidel, 1998)

\section{Collect Things}

This phase collects and sorts the data of performance, consideration in changes of Integrated Wonorejo Zone in first and second period, the legal basis of zone development, as well as executed inovation.

\section{Thinking about Things}

The thinking process examines the data which have collected. We build some type of sense out of each collection especially which can be proved. Second, we assess the relationship of information from BAPPEDA, Department of Agriculture, and Tourism, Art and Culture Office. This study discovers the phenomena with general description on performance, inovation and consideration in changes from informant, document and field observation.

\section{RESULTS \& DISCUSSIONS}

\section{First and Second Period Condition}

Condition of Integrated Wonorejo Zone in first and second period looks indifferent. According to Cristaller (1966 in Sullivan, 2005) on central place theory, the concept of integrated wonorejo zone in first periode become the center of place to provide goods and services to recidents of the surrounding area. The facilities include the public service, education and training, research, information and integrated economy, which is the implementation of Tri Program Plus of Lumajang. The facilities consist of several Integrated Wonorejo Zone fields such as agriculture, SME, tourism, transportation and other supporting facilities. Agriculture sector consists of the Department of agriculture, agrotourism, green house, agro stand, and agro tourism education and training. Small and Medium Entreprises (SME) consist of warehouses rebate, rest zone and restaurant. Whereas tourism sector consists of information centre and 
children's play ground, and the sector of transportation provides a bus terminal. Last is the supporting facilities, i.e. mosque, open stage, clean water, electricity, phone outlets and 24hour security system.

Accordance to central place theory by Cristaller, this zone is not appropriate to become central of public service, because in the first concept of this area is to improve economic revenue of Lumajang Regency. Distance between the zone and central of bussines area of Lumajang Regency is too far. Considering the concept of Cristaller about range and treshold, decision from Lumajang Regency to establish this zone in Wonorejo District is bad. Recently, the condition of the zone is not maintained well due to seldom visitors.

Integrated Wonorejo Zone in second period is not different with previous period. But there are several function-changed facilities. However, there is also zone area which still continues to be developed. The basic law regarding management on Integrated Wonorejo Zone has been established through Regent of Lumajang Decision No. 188.45/372/427.12 on 2003 which regulate the establishment of management team for Integrated Wonorejo Zone. In detail, the facilities in the Integrated Wonorejo Zone which is currently functioned are Water Park, Circuit of Motor Cross, Outbound Arena, Central of handy crafts and Bird competition arena. These existing facilities are plastered on the light billboard at the entrance of Integrated Wonorejo Zone.

Some facilities are changing due to unsustainable development. Another reason is due to lack of commitment from the leaders of the zone to the development.

Similar with the condition of the first period, and compare to the theory of central place by Cristaller (1966), this zone is further from first period. Although the change is not significant, the change of zone concept is not logic. Cristaller stated that central place is a center of public service. Integrated Wonorejo Zone can be mentioned as central of public service, because many facilities and function of building is to serve people. But in fact, the condition is not sustainable because the zone has not considering several aspect of central place. Specification of central place acording Cristaller that the place must be consider the treshold. It means that central place should serve all people that live there.
The Integrated Wonorejo Zone was established far $( \pm 5 \mathrm{~km})$ from Central Bussines District (CBD) of Lumajang Regency. The impact is the government cannot achieve the concept to provide people needs on recreation. Cristaller theory of central place obviously explained that central place should provide all people's need who live there. Thus, its questioned which people were served if they live far from the zone.

\section{Implementation}

Implementation of Integrated Wonorejo Zone in first period is not going well like its original concept. It has been described previously that the implementation of Integrated Wonorejo Zone has been regulated in the Regent Decision on the establishment of management team. It explained that there are agency and the associated body that has the responsibility of the facilities in the zone.

Management of Integrated Wonorejo Zone in the first period was managed separately. Initial management was managed by government secretariat of Lumajang. Otherwise, area that has building which more emphasize to improve economic revenue of Lumajang was managed directly by economic division. Several place also managed by general affair division. The separate management dificult the improve execution of Integrated Wonorejo Zone at that time.

Reviewed from the theory of policy change by Howlett and Cashore (2009), change of policy include in goals, program and operational. Implementation of Integrated Wonorejo Zone in second period did not experience significant changes. However, differentiation of policy in first and second period is operational. Former zone management which directed separatelly, change into integrated operational. Howlett and Cashore explained that one change which regulated by the policy is the goals. Integrated Wonorejo Zone in first period have goals as recreation and attraction site. Many building established in the form of game and play ground, an effort to support economic revenue for Lumajang.

Implementation of Integrated Wonorejo Zone in second period is not clear on the concept or goals. In one side, the playground is still work, but several unsustainable building is functionchanged into governmental office and department. Circuit of motor cross was established behind the building - again, the goals for establishing this facility are not obvious. Tourism concept and public service cannot be located together. Tourism building become 
ineffective in the workdays of civil servant. Only Saturday and Sunday the playground in Integrated Wonorejo Zone can be operated. This proved that the concept change of Integrated Wonorejo Zone is not clear compared to policy change theory by Howlett and Cashore (2009). Implication

We compared the implication in Integrated Wonorejo Zone on both first and second period. The implication observed between each policy change in Integrated Wonorejo Zone, Lumajang (Table 1).

Table 1. Implication of Integrated Wonorejo Zone

\begin{tabular}{|c|c|}
\hline First period & Second period \\
\hline $\begin{array}{l}\text { - The increased value of } \\
\text { the land sale }\end{array}$ & $\begin{array}{l}\text { - The increased value of } \\
\text { the land sale }\end{array}$ \\
\hline - Increased Revenue & - Increasing Revenue only \\
\hline - Increasing population & from waterpark. \\
\hline - Aculturation & - Increasing population \\
\hline
\end{tabular}

Each period have four points of implications for community and government. Four points in the first period are increasing community's economy, increasing the value of selling the land, rising the native incomes of the zone and an increase in population. Similarly, implications on the second period are also increased the value of the land sale, and increasing the number of population, while the increaseing revenue only came from waterpark fares. Thus, implications of the first to second period are not significantly different.

\section{CONCLUSION}

Policy change implication toward Integrated Wonorejo Zone is not significant. After Integrated Wonorejo Zone executed by RTRW 2008-2028, manager of this zone is Tourism, Art and Culture Office of Lumajang Regency, while before managed by more than one institution in department level. Budgeting activity by Tourism, Art and Culture Office is limited to improve the condition as well as lack of human resources and finance.

Before setting the spatial planning, Lumajang government has taken the decision to change the Integrated Wonorejo Zone into an office building and department with consideration of utilization although lack of maintenance and finance. It is sharp contrast when they previously arise and define the spatial zones as a strategic area ofeconomic development. The implications of changes in the zone look indifferent from the first period.

\section{Recommendation}

The concept of an integrated Wonorejo Zone needs to be reviewed and determined as a consistent concept for economic development zone, because this zone is expected to contribute to the development of the economy.

Lumajang Regency must decide a proper policy for Integrated Wonorejo Zone to achieve the goals of becoming the zone of strategic economic development, and emphasize more on tourism sector. Otherwise, the policy applied to transform Integrated Wonorejo Zone into integrated agency to improve public service and administration affair in Lumajang.

It also important to improve the status of tourism in the level of management that is more adapted to the function of the facility in the zone. It is because the assets submission to the Office of Tourism, Arts and Culture, Lumajang was felt less precise.

\section{REFERENCES}

[1] Christaller, W. 1966. Central places in Southern Germany. In: Sullivan, A.O. 2005. Market areas and central place theory, Journal of Economic Development 13 (4), 113.

[2] Howlett, Cashore. 2009. The dependent variable problem in the study of policy change: understanding policy change as a methodological problem. Journal of Comparative Policy Analysis: Research and Practice 11(1), 33-46.

[3] Lumajang Local Government. 2001. Integrated Area Development of Wonorejo: Trigger for future development of Lumajang. Lumajang, Local Government of Lumajang.

[4] Lumajang Local Government. 2008. Spatial Planning of Lumajang Regency 2008-2028. Lumajang, Local Governement of Lumajang.

[5] Lumajang Regent Decree No. 188.45/372/ $427.12 / 2003$ on management team of Integrated Wonorejo Zone. Lumajang, Lumajang local Government.

[6] Grindle, M. 1991. Public choice and policy change. Journal of Public Policy. London. The Johns Hopkins University Press.

[7] Seidel, J. 1998. Qualtitative data analysis. Newburry Park, Sage Publication. 